\title{
A tale of two skeletons?
}

\section{Greco-Turkish cultural memory, sacred space, and the mystery of the identity of the occupants of a now lost ciborium Byzantine tomb at Trebizond}

\begin{abstract}
The body of almost every Roman or Byzantine emperor has been lost. This piece draws attention to two skeletons, recovered from a Muslim türbe at Trabzon during World War I by the Russian excavator Feodor Uspensky. Using local oral tradition, Uspensky identified the two bodies he recovered as the Byzantine emperor of Trebizond Alexios IV (1417-1429) and a local Turkish hero Hoşoğlan. Since Uspensky, his identifications have not been challenged nor scientifically examined. This paper argues that Uspensky did not recover just one but two imperial skeletons. It first dissects his identifications, showing how competition for sacred space between Greeks and Turks in the Ottoman period led each community to identify the tomb's occupants with foundational figures in their communities. After dissecting Uspensky's identifications, this paper then makes the case that both occupants of this tomb were unidentified members of the Grand Komnenoi family, urging for scientific examination of what may be the only bones of a Byzantine emperor.
\end{abstract}

Adresse: Dr. Scott Kennedy, Bilkent University, Main Campus, G Building, 24/g, 06800 Bilkent-Ankara, TURKEY; scott.kennedy@bilkent.edu.tr

This piece began from a conversation with Nancy Ševčenko about imperial tombs when she pointed me to the tomb of Alexios IV at Trebizond. In writing this article, I have incurred a debt to many individuals. Many thanks are due to Dimitrios Sidiropoulos, Jason Jingxuan Li, and Commission for Pontic Studies for helping me obtain material. Artemy Streletsky generously checked my English translations from the Russian. The Istituto Ellenico is also due thanks for granting permission to use figure 3. I also owe my gratitude to Rustam Shukurov, Sima Meziridou, Anthony Kaldellis, Nathan Leidholm, and BZ's two anonymous readers for reading and commenting on this long paper. Finally, Anna Tsipkina kindly read the parts on Uspensky, correcting my mistakes and sent me her published material. This paper would be impossible without her tireless exploration of Russian archives. All errors are my own. 
For historians, the study of the body of a dead ruler can provide a wealth of new information about what life was like for the most privileged members of a society. In Western Europe, it is relatively easy to find the bodies of dead rulers, as many of their bodies are still entombed in their original resting places. Occasionally, it is even possible to make quite astounding discoveries, such as the recent recovery of the skeleton of King Richard III of England found beneath a parking lot. When analyzed by modern science, his body has shed light on the infamous king's hunchback appearance and even thrown into question the legitimacy of the patrilineal royal York line. ${ }^{1}$

However, for those who study the Roman empire from antiquity until its final end in 1461 with the fall of the empire of Trebizond, this situation is enviable. A mixture of pillage, cultural practices, and time have consigned the body of practically every Roman emperor to oblivion. Early Roman emperors such as Augustus, whose mausoleum was recently restored, were cremated and thus whatever data their body might have preserved was lost. ${ }^{2}$ After the second century A.D., burial became more common, as emperors increasingly built mausolea such as the mausoleum of Honorius (395-423) in Rome. ${ }^{3}$ But their bodies do not appear to have survived subsequent pillaging and later reappropriation of these spaces. For example, in 1544, as construction of the modern Saint Peter's Basilica was underway, workmen unearthed the sarcophagus, body, and jewels of the empress Maria (d. 408), the wife of Honorius and daughter of the noted general Stilicho in the Mausoleum of Honorius. However, they reburied her in a public ossuary, while her jewels were subsequently melted down and dispersed. ${ }^{4}$

In the eastern Roman empire, the survival of imperial burial places was somewhat better, as the Roman state had every interest in preserving the memory of its great emperors. As it is well known, Constantine and later Justinian built mausolea near the Church of the Holy Apostles, which housed the bodies

1 T.E. KING et al., Identification of the remains of King Richard III. Nature Communications 5 (2014).

2 On early imperial burials, see P.J.E. DAvies, Death and the emperor: Roman imperial funerary monuments, from Augustus to Marcus Aurelius. Austin 2004. The stone funerary inscriptions of a few imperial family members survive such as Agrippina the Elder (CIL VI, 886) and the Antonines (CIL VI, 984-995).

3 M. Johnson, The Roman imperial mausoleum in late antiquity. Cambridge 2014; M. McEvoy, The mausoleum of Honorius: late Roman imperial Christianity and the city of Rome in the fifth century, in R. McKitterick et al. (eds.), Old Saint Peter's, Rome. Cambridge 2013, 119-136. 4 F. PAolucci, La tomba dell' imperatrice Maria e altre sepolture di rango di età tardoantica a San Pietro. Temporis Signa 3 (2008), 225 - 252; JoHnson, Roman imperial mausoleum (as footnote 3 above), $171-174$. 
of most emperors up until the eleventh century. ${ }^{5}$ Afterwards, subsequent dynasties tended to erect or designate a church as their primary burial site, such as the Pantokrator Monastery, which served as the final resting place of members of the Komnenoi and Palaiologoi dynasties. ${ }^{6}$ But the Turkish sack of Constantinople in 1453 largely obliterated their bones, as the pillaging army ripped open tombs, cast the bones to the ground, and crushed them underfoot "as they lay amidst the dung."7 Under Turkish rule, whatever remained of imperial burials was almost entirely destroyed, as Mehmet II (1453-1481) subsequently bulldozed the Holy Apostles in 1458/9 to make room for his namesake mosque, the modern Fatih Sultan Mehmet Camii, and ordered the conversion of the Pantokrator monastery into a medrese in $1453 .{ }^{8}$ Up until 1587, a tomb of Alexios I Komnenos (1081-1118) or possibly an empress of Trebizond may have survived in the Pammakaristos Church (Fethiye Camii) occupied by the patriarchate of Constantinople; however, the tomb was ultimately destroyed when Murad III (1574-95) converted the church into a mosque, as he sought to expel Orthodox Christians from within Istanbul's walls. ${ }^{9}$ Today, a few sarcophagi of the emperors may survive, but the conquest and subsequent repurposing of Byzantine spaces as Turkish mosques and medeses renders the prospect of ever finding an emperor's body bleak despite 1100 years of history. ${ }^{10}$ For other imperial Byzantine cities that sur-

5 P. GRIERSON, The tombs and obits of the Byzantine emperors (337-1042), with an additional note. DOP 16 (1962), $1-63$.

6 S. KotZABASSI, The Monastery of Pantokrator between 1204 and 1453, in S. Kotzabassi (ed.), The Pantokrator Monastery in Constantinople. BA, 27. Berlin 2013, 67-69.

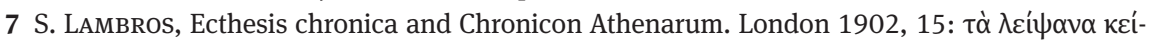

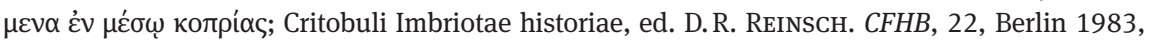
72; A. SANJiAn, Colophons of Armenian manuscripts, 1301-1480. Cambridge, MA 1969, 242. 8 The date of the destruction of the Holy Apostles is given by the contemporary historian Kritoboulos: REINSCH, ibid. 140. For Mehmet's order to convert the monastery into a medrese, see T. Öz, Zwei Stiftungsurkunden des Sultans Mehmed II Fatih. Istanbul 1935, 11. On the other imperial burial churches, see N. MeLvani, The tombs of the Palaiologan emperors. BMGS 42 (2018), $237-260$.

9 On the tomb, see P. SchreINER, Eine unbekannte Beschreibung der Pammakaristoskirche (Fethiye Camii) und weitere Texte zur Topographie Konstantinopels. DOP 25 (1971), 224 with commentary at 237-239; H. Belting / C. A. MANGo / D. Mouriki, The mosaics and frescoes of St. Mary Pammakaristos (Fethiye Camii, at Istanbul). Dumbarton Oaks studies, 15. Washington, DC 1978, $32-33$; see 1-37 for the history of the church. A contemporary Venetian ambassador

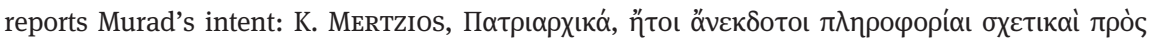

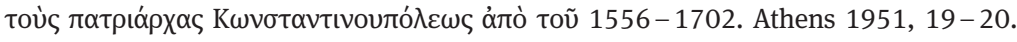

10 A. A. VASILIEv, Imperial porphyry sarcophagi in Constantinople. DOP 4 (1948), 1-26; C. MANGo, Three imperial Byzantine sarcophagi discovered in 1750. DOP 16 (1962), 397-402. 
rendered to the Turks, the fate of the emperors was similar. After the empire of Trebizond and its rulers the Grand Komnenoi surrendered to the Ottomans in 1461, Mehmet II converted the city's metropolitan church and monastery, the Chrysokephalos, into a mosque (Ortahisar Camii) and a medrese. ${ }^{11}$ Although we know that the church had been used as the principal burial site by the Grand Komnenoi as early as the reign of Andronikos I Gidos (1222-1235), study of the church's interior has not revealed any trace of the Grand Komnenoi's tombs, though a fragment of a church official's funeral epitaph has been discovered nearby. ${ }^{12}$

All of this makes the discovery of even a single Byzantine emperor's body a find of great significance. In September 1916 during the Russian occupation of Trebizond in World War 1, precisely this may have happened. In the courtyard of the Chrysokephalos to the east of the church, where now lies a subterranean toilet, there once stood a türbe dedicated to the Turkish hero of the siege of Trebizond in 1461 called Hoşoğlan. He was popularly credited with shooting the cannon shot that brought down the chains that fastened gates of Trebizond, thereby forcing the city's surrender. In some traditions, he had allegedly reported the feat to Mehmet II, who killed the hero in disbelief, only later realizing his error and lamenting, "hoş, oğlan (well done, young man)."13 Hoşoğlan's tomb consisted of a square wooden structure supported by four marble columns across whose ceiling hung a chain on which a decomposing cannonball was suspended. Locals claimed the cannonball was none other than the hero's miraculous shot. Below the cannonball was an empty wooden coffin covered in green felt with a green turban at its head. ${ }^{14}$ Near the coffin was a wooden plaque with an inscription honoring the hero in Ottoman Turkish: ${ }^{15}$

The tombs of the last Palaiologoi princes survive in Rome: Melvani, Tombs (as footnote 8 above), 260 note 114 .

11 M. AK, Aşık Mehmed - Menazirü'l-Avâlim. Ankara 2007, 1022 - 23; Z. MEHmed, Evliya Çelebi, Seyahatnamesi. Istanbul 1978, 456; see also H. LowRY, The Islamization \& Turkification of the city of Trabzon (Trebizond), 1461-1583. Istanbul 2009, 33-34.

12 On the church, see A. BRYER / D. Winfield, The Byzantine monuments and topography of the Pontos. Dumbarton Oaks studies, 20. Washington, DC 1985, 238-243.

13 See below for further discussion.

14 No photo of the türbe survives. The most detailed descriptions by eyewitnesses are S. MiNTSLOV, Соборь Богородицы-Златоглабой, Сборник статей, напечатанных в газете Трапезондский военный листок за 1916-1917 гг - “Трапезондский военный листок”, газета. 1917, 81-84: 82, accessible at: https://rusneb.ru/catalog/000200_000018_v19_rc_2067260/.

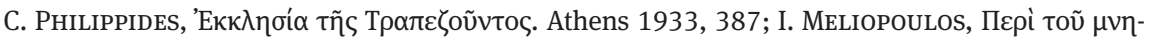

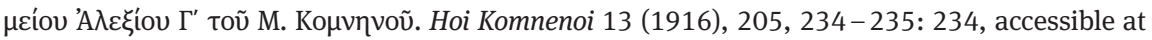
https://archive.org/details/oikomnenoi; H. LYNCH, Armenia, travels and studies. London 1901, 22. 


\author{
Bu el-fethi hazret-i gâzi Mehmed hanla \\ eyledi. Feth-i Trabzona gelüb say-ı cihad \\ bir tob endaht iderek fethine oldu bâdî. \\ Bu Hoşoğlan serini virdi idüb istişhâd \\ eyledi târih-i fethiyesini ehl-i rûz 866 (1461).
}

This man won victory along with glorious Gazi Mehmet Han. He came to the conquest of Trebizond, a labor of jihad. Shooting a cannonball, he was responsible for its conquest. This Hoşoğlan gave his head and achieved martyrdom. Mortal people date the conquest as 866 (1461). ${ }^{16}$

From all appearances, this was a Turkish burial for a şehit of the siege of Trebizond, but over the course of the nineteenth century, a number of Christian observers had remarked that the türbe was supported by four Byzantine columns with crossed-out crosses in the pediments. As the türbe was just to the east of the altar of the Grand Komnenoi's burial church, the Russians under the aegis of the Byzantinist Feodor Uspensky decided to excavate the site believing an emperor might lie beneath. Collecting up the tomb's accoutrements and the inscription, he gave them to the mosque's mullah and tore down the wooden structure to reveal a square ciborium tomb structure. ${ }^{17}$

After removing the türbe's wooden floor and breaking through a layer of cement, Uspensky scooped out water and dirt to reveal the outlines of a stone sarcophagus about $93 \mathrm{~cm}$ ( 3 feet) below the original floor. As he scooped through the dirt and water inside the tomb, he found fragments of bone, jewels, and finally a skeleton. This first skeleton hardly interested Uspensky, who believed it was a Turk and devotes hardly a line to it in his diary or reports of his findings. ${ }^{18}$ But it made quite an impression on his collaborator Sergei Mintslov, who vividly describes it in his report for the Russian army's newspaper:

15 A photograph and Russian translation of the inscription are produced in F. UsPENSKY, Усыпальница трапезундского императора Алексея IV Комнина. VV 23 (1917), 1-14: 8. An im-

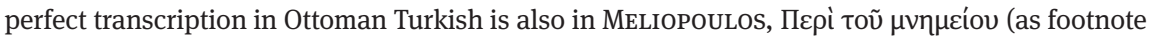
14 above), 234.

16 In Ottoman inscriptions, it is common to give dates with words whose characters sum to the year. I simply give the year here. Unless otherwise acknowledged, all translations are my own. 17 A. TsYpKinA, “Прибыл в Трапезунт на миноносце...”: Записная книжка академика Ф.И. Успенского. 1916 г. Istoričeskiy archiv 2017/4, 123 -159: 142; USPENSKY, Усыпальница (аs footnote 15 above), 8, 10; F. USPENSKY, Второй отчеть о занятияхь вь Трапезунте и откресностяхь (6). Izvestiya akademiy nauk 40 (1917), 1657-63: 1660-61; MinTSLov, Соборь (аs footnote 14 above), 82. For a discussion of the ciborium tomb, see below and N. ŠEvčENKo, The tomb of Manuel I Komnenos, again, in A. Ödekan et al. (eds.), Proceedings of the First Sevgi Gönül Byzantine Studies Symposium, June 25-28, 2007. Istanbul 2010, 609-616. 18 See the preceding footnote. 


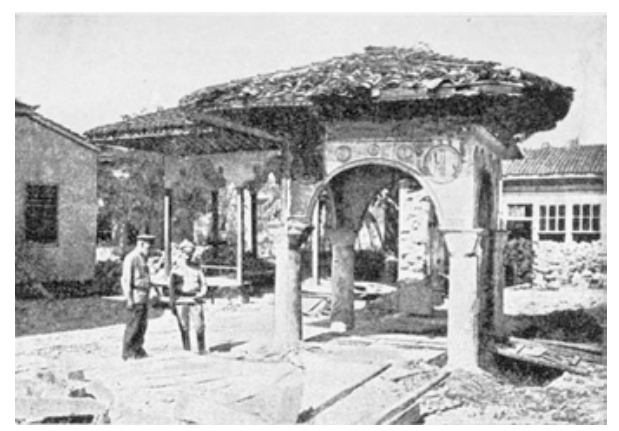

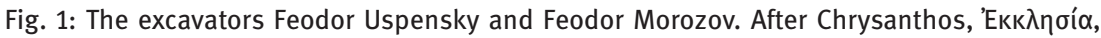
fig. 10.

Поди деревянными надгробіемъ открылась, облицованная белыми мраморными плитами, могила; на небольшой глубине въ ней лежалъ мужской скелетъ. Осмотръ костей и, главнымъ образомъ, черепа разрешилъ легенду о юномъ пастухь: такова участь археологіи, призванной замьнять фантастическіе вымыслы дьйствительностью! Скелетъ оказался принадлежавшимъ взрослому человьку; швы его черепа были плотно зацементованы, что указывало на пожилой возрастъ покойника. И, главное, черепъ, необычайными формами своими, свидетельствовалъ, что онъ принадлежалъ несомненно юродивому самыхъ низменныхъ ступеней. Поразительньйшей особенностью черепа являлось разделеше у него, обычно сплошной лобной кости, швомъ, ведшимъ отъ середины левой глазной орбиты къ темени.

Under the wooden gravestone, there was revealed a tomb with white marble columns. At a small depth below, there lay within a male skeleton. Examination of the bones and mainly the skull resolved the legend about the young shepherd. Such is the fate of archaeology, called upon to replace fantastical fabrications with truth. The skeleton was found to belong to an adult individual. Its joints were tightly fused to the skull, which indicated the elderly age of the deceased. And the skull due to its exceptional form testified that it indubitably belonged to a lunatic of the lowest class. An astonishing peculiarity of the skull was a division in it of the usually continuous frontal bone with a joint leading from the middle of the left eye socket to the crown of the head. ${ }^{19}$

As the excavators dug below the first skeleton in the sarcophagus, they plowed through a mix of mud, water, and slime. Their work was hampered by groundwater which kept seeping into the pit despite trenches dug to divert it. Frustrated by the water, they finally decided to terminate the excavations and remove whatever else lay in the sarcophagus. Below the muck at the very bottom of the sarcophagus, they found a clay vessel and the legs, pelvis, and skull of a second

19 Mintslov, Соборь (as footnote 14 above), 82 - 83. Cf. S. MintsLov, Трапезондская Епопея. Дненикь. Berlin 1925, 130. 
skeleton. ${ }^{20}$ As the skeleton was not at the center of the sarcophagus and the sarcophagus appeared damaged at the bottom, Uspensky believed it had been disturbed by graverobbers during the conquest of Trebizond in 1461. Uspensky was unable to complete his work due to the suspicions of the locals. However, he was confident that he had uncovered the skeletons of the Turkish hero Hoşoğlan and emperor Alexios III of Trebizond (1349-90). As locals believed that the emperor John IV (1429-1460) nicknamed Kaloioannes had built a tomb for his greatgrandfather Alexios III in the Chrysokephalos complex, local oral tradition led Uspensky to make this identification. ${ }^{21}$ However, he later slightly modified his thesis. Based on a passage in the fifteenth century Byzantine historian Laonikos Chalkokondyles that John IV, "honored his father [Alexios IV (1417-1429)] with all due respect at his burial. He laid him to rest in the monastery of the Theoskepastos, although he later brought him to the capital,"22 Uspensky subsequently reidentified the second skeleton as Alexios IV (1416-1429). ${ }^{23}$ It made more sense for John to have built a tomb for his father, not his great-grandfather.

After completing work at the tomb, Uspensky restored the ciborium to how it might have looked under the Grand Komnenoi at his own expense. ${ }^{24}$ Some Russians hoped to transform the Chrysokephalos Church into a museum. ${ }^{25}$

However, the Russian revolutions of 1917 disrupted these plans. In the ensuing havoc, the Russian occupation of the city collapsed. Uspensky's restoration of the ciborium tomb seems to have painted a figurative bullseye on it. When the Turks retook the city in 1918, a Turkish major blew up the site. ${ }^{26}$ The remnants of the columns and sarcophagus were apparently later reincorporated into a garden which subsequently became the modern Atapark about half a kilometer to the west of the city center. ${ }^{27}$ A local school teacher Mahmut Kemal Yanbey

20 UsPENSKY, Второй отчеть (as footnote 17 above), 1661; TsYPKinA, Прибыл (as footnote 17 above), $142-144$.

21 On the identification see below.

22 Laonici Chalcocondylae Historiarum Demonstrationes, ed. J. DARKó. Budapest 1923, 220:

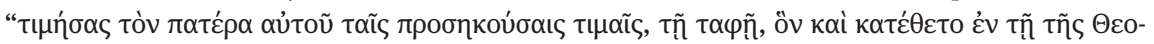

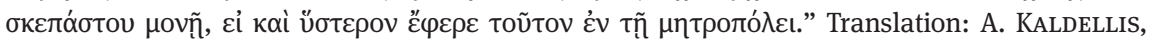
Laonikos Chalkokondyles, The Histories. Dumbarton Oaks medieval library, 33. Washington, DC 2014, 309.

23 USPENSKY, Усыпальница (as footnote 15 above), 14.

24 Ibid.

25 G.E. Sheglov, Хранитель. Жизненный путь Федора Михайловича Морозова. Minsk 2012, $140-141$.

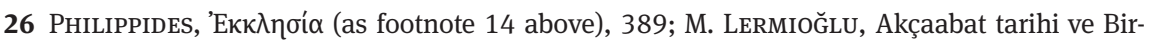
inci Genel Savaş - hicret hâtıraları. Istanbul 1949, 68.

27 LERMioĞLU, Akçaabat (as footnote 26 above), 69. 


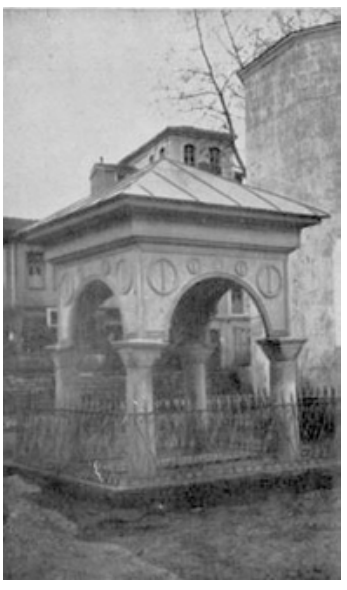

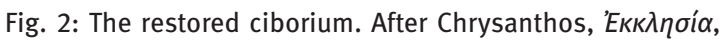
fig. 11 .

and the Trabzon müfti Süleyman Eyüpoğlu claim to have seen the columns of the türbe there in $1946{ }^{28}$

Just like the remnants of the tomb, the bones of the emperor underwent their own odyssey. Uspensky surrendered them to the metropolitan of Trebizond Chrysanthos in 1917, who reburied them in the metropolitan church of Saint Gregory in $1918 .{ }^{29}$ When the exchange of populations took place in 1923, they would have been left behind, were it not for Georgios Theodoros Kandilaptis, a Pontic official in the Populations Exchange Commission, who smuggled them to Greece among his possessions and deposited them in the Museum of Byzantine Civilization in Athens. ${ }^{30}$ They remained there until 1980 when they were transferred, without any scientific examination, to the (New) Soumela monastery in Veria and reburied with much pomp in the monastery's museum, where they have remained until today. ${ }^{31}$

Since the excavations, Uspensky's identifications of the skeletons he discovered has never been challenged nor tested scientifically. Indeed, the noted historian of the empire of Trebizond, Anthony Bryer, writes that, "it is also now too late

28 H. EDHem, Trabzon'da Osmanli kitabeleri. Trabzon 2001, 65.

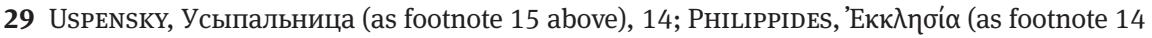
above), 318.

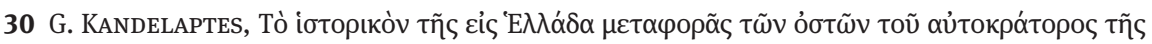

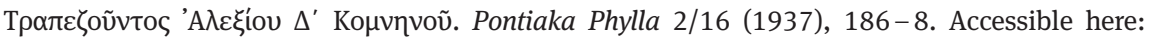
http://epm.omegatechnology.gr/magazine.aspx?id=2003

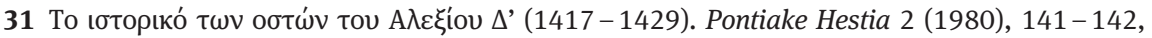
$233-249$. 
to challenge the obvious conclusions which Uspenskij drew as to the identity of the two skeletons." ${ }^{32}$ However, since Bryer wrote these words, numerous other sources have become available through digitization and a renewed interest in the Russian occupation of Trebizond spurred by its centennial anniversary. ${ }^{33}$ Using these Russian, Greek, and Turkish sources, this paper challenges Uspensky's identification of the bodies in the türbe. It argues that Uspensky uncovered not one but two Byzantine imperial burials. The first part of this paper will (1) dissect what we know about the Hoşoğlan türbe and (2) demonstrate how both Hoşoğlan and the emperor Alexios were manufactured in popular and scholarly memory to control the space around Chrysokephalos church/Ortahisar mosque. More broadly, this section will offer a Trapezuntine/Trabzonlu casestudy of how Greeks and Turks, Christians and Muslims, fought over shared sacred space and historical memory in the Ottoman period. ${ }^{34}$ After exploring this process, this paper will then turn to the identification of the bodies based on what we concretely know about the site, suggesting that the Turks and subsequently Uspensky uncovered two imperial burials. Without further scientific study of the skeletons, this identification is only tentative, but I offer it in the hope that it will spur further work on what may be the only surviving bodies of Roman emperor(s).

\section{The Hoşoğlan türbe between Greeks and Turks}

In order to understand who is buried within this tomb, it is necessary to step back in time and explore the popular and often polemical oral tradition surrounding the tomb. Our knowledge of the area around the Chrysokephalos is quite patchy until the early nineteenth century. Ottoman observers, Mehmet Aşık (1598) and Evliya Çelebi (1645) briefly describe the mosque and medrese.

32 A. BRYER, The faithless Kabazitai and Scholarioi, in A. Moffatt (ed.), Maistor: Classical, Byzantine and Renaissance studies for Robert Browning. Byzantina Australiensia, 5. Canberra 1984, 309-327: 326.

33 A. TsYPкINA, Трапезунтская научная еспедиция 1916-17 гг. Новые архивные материалы, in: The Black Sea region in the Middle Ages. Moscow 2015, $212-237$; H. AкARCA, İşgal döneminde Trabzon'da Rus politikaları (1916 -1918). Karadeniz İncelemeleri Dergisi 7 (2009), $141-152$; H. AKARCA, Imperial formations in occupied lands: the Russian occupation of Ottoman territories during the First World War. Princeton, N.J. 2014. Many helpful watercolors from the expedition, including watercolors of the türbe, have also been made available by the Saint Petersburg branch of the Russian Academy of Sciences: http://ranar.spb.ru/rus/vystavki/id/561/. 34 Following E. BARKAN/K. BARKEY, Choreographies of shared sacred sites. Religion, politics, and conflict resolution. New York 2014. 
However, they are silent on the türbe, even though they were clearly very familiar with the area around the mosque. ${ }^{35}$ Evliya even discusses the city's notable funerary monuments but he does not mention Hoşoğlan's tomb, even though he knew of a stream and village called Hoşoğlan near Mount Minthrion (Boz Tepe) to the southeast of Trebizond associated with a clan of shepherds. ${ }^{36}$ Even though many Western travelers visited Trebizond between the fifteenth and nineteenth century and a few of them left very detailed descriptions of its monuments, almost none of them discuss the Chrysokephalos. Its use as a mosque in a mainly Turkish neighborhood apparently deterred them from closely inspecting it. ${ }^{37}$ The first mention of the türbe appears in the travel report of the Armenian scholar Minas Bzhshkean, who visited the city around 1819:

On the eastern side of the courtyard we saw an old square building with marble columns, whose pediment was decorated with marble crosses. Part of the building stands within a house. It would seem that previously the courtyard extended as far as the street and the [church's] zhamatun was on the other side. ${ }^{38}$ The western part of the building looked on the courtyard where a body of a martyr was found. It seems that there was a cemetery of martyrs and the body of Eugenios must be there too. In the eastern part of the shrine, near the Zağanos door [of the Chrysokephalos] a coffin is also displayed, and they say that the body of a martyr is inside. Both this one and the other body buried in the columned building, the Muslims revere with honor. There is coffin here with an inscription in a foreign language. On the one that is in the square is inscribed: Sultan Gazi Mehmet Han ibn Murad, 865 of Hegira, who is sultan Mehmet [II], and this inscription was written in the year 1461 when the city was taken. ${ }^{39}$

From Bzhshkean's account, it is clear that in 1819, Turks were revering two bodies of martyrs (probably şehits), each not far from the other. Apparently, both had been found at some point by the Turks, raising the suspicions of local Greeks, who believed the bodies of Byzantine holy men lay within, including possibly Saint Eugenios, the patron saint of Trebizond. But as far as one can tell, neither

35 Ak, Aşık (as footnote 11 above), 1022-23; Menmed, Evliya (as footnote 11 above), 456. 36 MeHMed, ibid. 460.

37 E.g., C. PhilipPIDEs, Relation d'un voyage en Orient par Julien Bordier, écuyer de Jean Gontaut, Baron de Salignac, ambassadeur à Constantinople (1604-1612). Archeion Pontou 6 (1935), 85-158; J.P. de TOURNEFORT, Relation d'un voyage du Levant fait par ordre du Roy. 1717, 44-85. For a full list of Western travelers, see BRYER/WINFIELD, Byzantine monuments (as footnote 12 above), $\mathrm{xxx}-\mathrm{xxxiii.}$

38 In the Armenian ecclesiastical tradition, the zhamatun or gavit is usually a square narthex on the west side of a church.

39 M. Bzhshkean, Patmut iwn Pontosi or ē Seaw tsov. 1819, 67-68; M. Bzhshkean, Karadeniz kıyıları tarih ve coğrafyası 1817 -1819. Istanbul 1969, 47. I am grateful to Sima Meziridou and Michael Burling for assisting me with the Armenian. All errors are my own. 
the name of Hoşoğlan nor Alexios had attached itself to the site. Bzhshkean knew about Hoşoğlan and his grisly execution by Mehmet II, but he associated it with the creek and village of Hoşoğlan. ${ }^{40}$ As he personally visited the türbe, it seems probable that he would have made the connection between the two sites, had such a connection already existed. Bzhshkean's observations are consistent with the lore collected in the later 1860's by Periklis Triantaphyllides, the head of the Greek school in Trebizond, who writes that the local Turks alleged that the entombed was an unnamed dervish in the army of Mehmet II who shot the chain that held the gates of Trebizond shut with a cannonball and thus forced the Greeks to surrender. As he states, it was only less trustworthy Turks who told a more elaborate story of Hoşoğlan, a shepherd killed for refusing the sexual advances of Mehmet II after bringing him the keys of the city. ${ }^{41} \mathrm{He}$ also notes the burial of two individuals near each other at the Chrysokephalos in similar terms: "This tomb, which lies outside the Chrysokephalos, the ancient metropolitan church later converted into an Ottoman sacred space ( $\tau \dot{\varepsilon} \mu \varepsilon v o \varsigma)$, and another, which lies not far from the first, our people also claim as them as their own, surmising that they are hiding the relics of saints or some foreigners, which the piety of the Komnenoi hoarded in the city." 42

Who were these two individuals? When Uspensky undertook his excavations in September 1916, the tomb of Hoşoğlan was the only tomb in the area. Local Turkish lore is unhelpful. In his history of Trebizond written in 1876, just 6 years after Triantaphyllides, Şakir Şevket records only the tomb of Hoşoğlan. ${ }^{43}$ It would seem that at some point, the Turks unearthed both Uspensky's bodies and claimed they had found holy men, setting up cenotaphs for both. Eventually, the tomb outside the türbe was forgotten and merged with the Hoşoğlan türbe. A story of a victorious cannoneer attached itself to the site and was transformed into the Hoşoğlan story told to Uspensky. In any case, we can easily dismiss the Turks' tale of the şehit/dervish cannoneer. Eyewitness sources of the surrender of Trebizond in 1461 such as the Trapezuntine protovestarios George Amiroutzes and the Turkish functionary Tursun Beg report that the city was captured before Mehmet could deploy his cannons. Tursun even says "cannonball, rifle, and assault were not needed." 44

40 Bzhshkean, Patmut'iwn Pontosi, ibid. 91; Bzhshkean, Karadeniz, ibid. 58.

41 The conflation of Hoşoğlan and this şehit/dervish is an issue to which I return below.

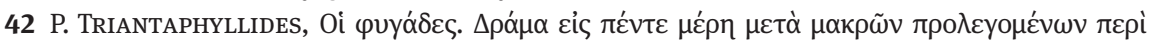
Пóvtov. Athens 1870, 19-20.

43 Ş. ŞEVKet, Trabzon tarihi. Trabzon 2001, $73-74$.

44 J.F. Boissonade, Anecdota Graeca, 5. Paris 1833, 394 - 395; A. Mertol Tulum, Tursun Bey. Târîh-i Ebü'l-Feth. Istanbul 1977, 110: topa ve tüfğe, yöriyişe ihtiyâc görülmedi. 
But this does not help us to understand why and how both Greeks and Turks identified the bodies in the tomb as Hoşoğlan and later Alexios III. In order to understand this, we need to see the Chrysokephalos complex as a contested religious space, a site where Christian and Muslim, Greek and Turk, fought for dominance over sacred space and cultural memory. After Mehmet II took the Chrysokephalos Church from them and made it into a mosque, the local Trapezuntine Greeks never forgot the site. From a later Greek poem about the alleged forced conversion of the Trapezuntine metropolitan church of Saint Phillip into a mosque (Kudrettin Cami) in 1665, it is clear that the conversion of the city's churches was a sore subject among the local Greek Orthodox. ${ }^{45}$ In a lament, the anonymous author lists all of the major churches of the city taken from the Christian community, beginning with the Panagia Chrysokephalos, exclaiming, "They took the famous church of the Mother of God, which is called the Chrysokephalos, an astounding church. The dominion of the Turks did not appear in these places in which it is now. The church's length of forty cubits, its width of thirty cubits, its height of thirty cubits, both the ground floor and the second floor, its bronze roof, its marble columns, [all these] burn our hearts and wear down our bodies." ${ }^{46}$ Similarly, Christians into the eighteenth century kept a tally of all the churches that had been taken from them and converted into mosques. ${ }^{47}$ For the Orthodox community, the seizure of their monuments passed into communal memory, becoming a foundational act of violence that defined their relationship with the Turks.

And so, when the Turks opened a Byzantine-era tomb with columns with scratched out crosses sometime in the eighteenth or early nineteenth centuries, they must have awoken religious strife, as curious Christians came prying, asking questions about their discovery and accused the Muslims of hoarding Byzantine treasures. To the Muslims, this area had been their space for centuries; therefore, a holy man of their faith must be buried there. It was only natural that the Turks would try to find a way to protect their religious space. At some point, their initial story of an entombed şehit or dervish was embellished. The şehit or dervish was given a heroic death during the conquest of Trebizond in 1461 under Mehmet II. Local Turkish memory held that the siege had been lengthy, only

45 BRYER/WinfiEld, Byzantine monuments (as footnote 12 above), 230.

46 A. Papadopoulos-Kerameus, Fontes historiae imperii Trapezuntini. St. Petersburg 1897, $151-152$.

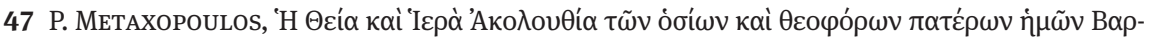

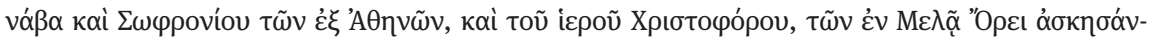

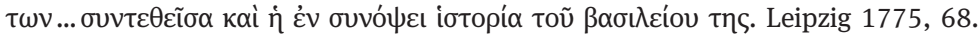


ended through Turkish bravery. ${ }^{48}$ Indeed, current popular memory remembers a violent surrender despite the best efforts of modern history. For example, when one visits the Trabzon Tarih Müzesi 'Trabzon History Museum' in the Ortahisar neighborhood, recent paintings depict smoking cannons and Ottoman troops pouring into Trebizond's demolished walls. ${ }^{49}$ Even though Trebizond peacefully passed into Turkish hands, attributing the site to a brave soldier of Mehmet II gave the local community legitimacy. Here was a monument that was synchronous with the beginning of the Ottoman Turkish community in the city, a foundational site that reminded the passersby of their just control of the site by right of conquest, for which the entombed was/were responsible. If the Greeks remembered the seizure of the Chrysokephalos as an act of violence, the Turks created an act of violence to legitimate their community.

But the Turks were not alone in this. As they sought to situate the Byzantine tomb within their community's memory, the Orthodox Greek community used similar methods to appropriate Turkish monuments for their community and maintain their community's hold on the Chrysokephalos site despite Turkish counterclaims and concrete evidence to the contrary. A few feet away from the Turkish türbe stood a fountain with a dragon-head spout, now destroyed, known by the Turks as Kulaklı Çesme. It appears to have largely been cobbled together from Byzantine spolia, such as the dragon-head spout and a funeral inscription for an official in the metropolitanate of Trebizond. ${ }^{50}$ Although the fountain included an inscription by Sinan Bey that asserted Sinan, a provincial governor under Bayazid II had built it, ${ }^{51}$ local Orthodox tradition as early as 1819 alleged that Alexios I Komnenos (1204-1222) had built the fountain after slaying a dragon. ${ }^{52}$ This tale probably derived from a long-standing tradition about a local hero slaying a dragon near a spring on Mt. Minthrion (Boztepe) and the

48 TRIANTAPHYLlides, Фvyádீৎ (as footnote 42 above), 18 - 19; ŞEVKET, Trabzon tarihi (as footnote 43 above), $73-74$.

49 When I visited the museum in October 2018, the images were on the second floor next to statues of the Ottoman sultans.

50 G. Millet, Les monastères et les églises de Trébizonde. BCH 19 (1895), 419-459: 424 -

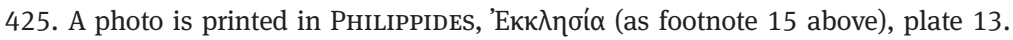

51 EDHem, Trabzon'da Osmanli kitabeleri (as footnote 28 above), 68-70; Ö. AKBULUT, Trabzon kitabeleri. Istanbul 1953, 27.

52 Bzhshkean, Patmut iwn Pontosi (as footnote 39 above), 63; Bzhshkean, Karadeniz (as footnote 39 above), 44; B. RotTIERs, Itinéraire de Tiflis à Constantinople par le colonel Rottiers. Bruxelles 1829, 205; LyNCH, Armenia (as footnote 14 above), 22. 
later Turkish village of Hoşoğlan..$^{33}$ In the time of the empire of Trebizond, the story was reassigned to the emperor Alexios II (1297-1330) by John Lazaropoulos (fl. 1360's), who calls the place where the dragon was slain Drakontopegadion (the dragon's spring). ${ }^{54}$ However, a variant where Alexios I slayed the dragon and built a commemorative spring ( $\pi \eta^{\prime} \eta$ ) outside the city, is recorded by Nikodemos of Colchis (fl. 1650) in his history of Trebizond. ${ }^{55}$ In his retelling of this earlier tradition, Parthenios Metaxopoulos (1775) made the spring a fountain (ßрúбıৎ). ${ }^{56}$

By the early 1800's, this fountain was identified with the dragon fountain near the former Chrysokephalos Church. Their appropriation of the fountain seems to have been particularly successful, as early Turkish historians of Trebizond at least repeat the story of Alexios as an alternative tradition explaining the fountain's origin. ${ }^{57}$ On its face, this appropriation was logical, as perhaps someone saw the fountain and imagined that the Turks had removed the dragon head spout from the fountain of Alexios I on Mount Minthrion. It did not hurt that the Greek funerary inscription incorporated into the fountain was worn down and difficult to read. ${ }^{58}$ It was easy to imagine that the Turks had simply restored Alexios' fountain as their own and difficult to disprove because of the illegibility of the inscription. But more broadly, the migration of the dragon tale from Mount Minthrion to the Chrysokepalos' Ottoman dragon fountain speaks to the Pontic Greek community's desire to symbolically re-establish itself and its history within a contested religious space. By asserting their primacy to the fountain with such a foundational figure as Alexios I, the Greeks asserted their primacy to

53 BRYER/WiNfIELD, Byzantine monuments (as footnote 12 above), 207. On dragon/serpent myths more broadly, see D. OGDEN, Drakōn: dragon myth and serpent cult in the Greek and Roman worlds. Oxford 2013.

54 J.O. RoSEnQvist, The hagiographic dossier of St. Eugenios of Trebizond in Codex Athous Dionysiou 154. Acta Universitatis Upsaliensis, 5. Uppsala 1996, 202.

55 Nikodemos' history does not survive, but an early draft of Metaxopoulos' history survives with this information attributed to him: Metaxopoulos, 'Aкoגov $\theta^{\prime} \alpha$ (as footnote 47 above),

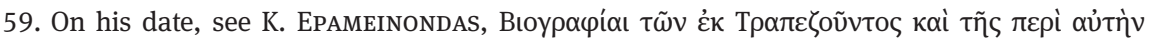

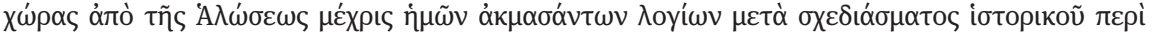

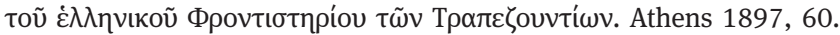

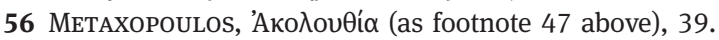

57 ŞEVkET, Trabzon tarihi (as footnote 43 above), 52 - 3; M. Öksüz, Trabzon Tarihi yazımı meselesi ve Ahmet Lütfi'in “Trabzon Tarihi” (1876-1950), 79-104: 97. Karadeniz İncelemeleri Dergisi 7 (2009) 97.

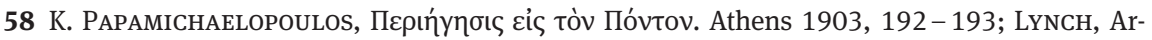
menia (as footnote 14 above), 22. 
the Chrysokephalos complex and could point to the object as proof of their community's long history in the city.

And so, just as Turks appropriated what was probably a Byzantine burial for their own in order to maintain control of this contested space, so the Greeks too did the same to the nearby Ottoman fountain. Each reassigned old artifacts to largely fictional stories and foundational figures in the memory of their community. Over the course of the nineteenth century and early twentieth centuries, the proximity of these monuments to each other and national pride seem to have led both communities to make the suppositions and assumptions that eventually led to the identification of the occupants of the Chrysokephalos tomb with their respective compatriots, Hoşoğlan and Alexios IV.

Among Turks, the proximity of the village of Hoşoğlan to Mount Minthrion and Alexios's dragon seems to have in some way encouraged speculation about the identity of the entombed. In our earliest recording telling (Evliya Çelebi), Hoşoğlan village received its name from a clan of shepherds, but later it became the spot where a local shepherd handed over the keys of Trebizond to Mehmet II and was killed. Some alleged that his execution was for refusing the conqueror's lust, deriving the place name from hoş oğlan, or 'beautiful youth. ${ }^{59}$ Others said that Mehmet had killed the youth in disbelief and realizing his mistake lamented, "Hoş, oğlan (Well done, youth)." ${ }^{60}$ But things changed in 1842 when Turks renovated the türbe and discovered what they believed to be the skull of a youth with a gash, none other than the first skeleton found by Uspensky. ${ }^{61}$ Indeed, local Turks afterwards called this area Kesikbaş 'Cut Head' or 'Gash Head'. ${ }^{62}$ This discovery seemingly fit the story of the violently executed Hoşoğlan, and so he became the occupant of the türbe. The shepherd who brought Mehmet the keys of the city was merged with the şehit cannoneer. ${ }^{63}$ There were of course Turks who struck to their original story that the entombed was a holy man even up until Uspensky's excavations. In 1916, Mintslov records that, "From what the mullahs say, a Muslim holy man was buried in the

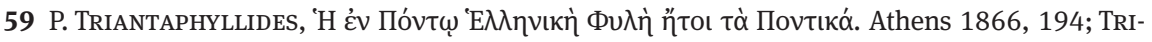
ANTAPHYLLIDES, Фuyádeৎ (as footnote 42 above), 19-20.

60 Bzhshkean, Patmut iwn Pontosi (as footnote 39 above), 91; Bzhshkean, Karadeniz (as footnote 39 above), 58; Lynch, Armenia (as footnote 14 above), 22.

61 ŞEVKET, Trabzon tarihi (as footnote 43 above), 75 note 1.

62 LERMIOĞLU, Akçaabat (as footnote 27 above), 69.

63 As in ŞEVKET, Trabzon tarihi (as footnote 43 above), 73-74. 
chapel." ${ }^{64}$ However, whoever created the wooden inscription honoring the entombed as Hoşoğlan certainly believed he was the shepherd.

As for how the Greeks and later Russians came to identify the entombed as Alexios IV, this is easier to track. When the first professional historian of Trebizond, the controversial Hellenist Jakob Philipp Fallmerayer, published his history of Trebizond in 1827, he wrote that John IV Kaloioannes "had built a magnificent memorial for his slain father [Alexios IV] in the metropolitan church of Trebizond." ${ }^{\circ 5}$ When he wrote this, Fallmerayer had never visited Trebizond. ${ }^{66}$ His words are little more than scholarly fantasy based on Laonikos' bald statement that, "[John IV] later brought [Alexios IV] to the capital." ${ }^{67}$ But subsequent visitors to Trebizond and the local Greek community consulted his text and repeatedly mention a 'beautiful tomb' of Alexios built by Kaloioannes as a 'chief ornament' inside the church ${ }^{68}$ By the early twentieth century, the tomb of Alexios had become something local Greek guides routinely mentioned, though they attributed the tomb to Alexios III $(1349-1390) \cdot{ }^{69}$ For some reason, they latched on to this burial rather than any of the other imperial or ecclesiastic burials in the church reported by the Byzantine historian of Trebizond, Michael Panaretos, such as the emperor John I (1280-1298) or Andronikos I Gidos (1222-1235). ${ }^{70}$ The local interpretation was even possibly flawed, as Chalkondyles' text only

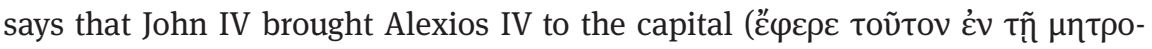
$\pi$ ró $\lambda \varepsilon 1)$. He could have been buried in any of the city's numerous churches. However, one must suppose that the scandalous manner of Alexios IV's death must

64 MintsLov, Соборь (as footnote 14 above), 82: “по словамь мулль вь часовне быль погребень какой-то мусульманский святой."

65 J.P. FAllmerayer, Geschichte des Kaiserthums von Trapezunt. München 1827: “... dem erschlagenen Vater ein prachtvolles Denkmal in der Metropolitankirche zu Trapezunt errichten liess."

66 He only visited the city in 1840. His impressions of the Chrysokephalos Church, without any mention of the türbe, are recorded in J.P. FallmeraYer, Fragmente aus dem Orient. Stuttgart $1877,64-66$.

67 DARKó, Laonici Chalcocondylae... (as footnote 22 above), 220.

68 C.F.M. Texier / R.P. Pullan, Byzantine architecture. London 1864, 199: "The tomb of Alexis, erected by Kalo-John, forms the chief ornament of the edifice. It consists of a marble mausoleum, adorned with bas-reliefs: it was executed between the years 1445 and 1449." PA-

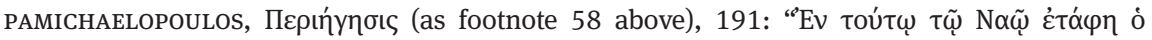

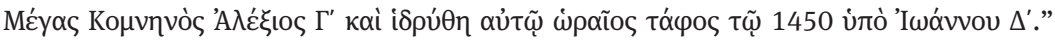

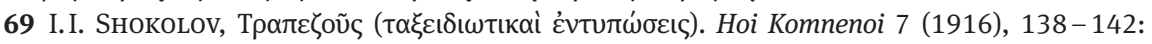

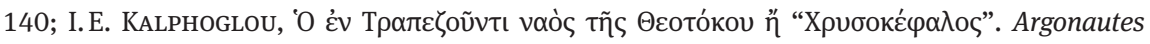
5 (1916), 9-10: 10.

70 S. KARPOV/R. SHUKUROv/ A. M. KRYUKov, Михаил Панарет. О великих Комнинах (Трапезундская хроника). Saint Petersburg 2019, 78, 100, 112. 
have played a role. According to this passage in Chalkokondyles, John had allegedly sent assassins to kill his father and then hypocritically buried his father in repentance. This dramatic story probably was memorable to locals, and perhaps they initially delighted in telling it to visitors. Eventually, however, locals began to confuse Alexios IV with Alexios III because of the dragon fountain. Although it was originally attributed to Alexios I, Fallmerayer's rediscovery of John Lazaropoulos's narrative of Alexios II slaying the dragon changed things. Following Fallmerayer who incorrectly identified Alexios II as Alexios III, ${ }^{71}$ Pontic Greeks quickly reidentified their Alexios I of the dragon fountain with Alexios III. ${ }^{72}$ Because of the fountain's proximity to the church, locals eventually lost track of all the Alexioi and merged Alexios III of the fountain with Alexios IV buried by Kaloioannes.

No Greek seems to have attempted to concretely identify the individual entombed in the türbe of Hoşoğlan as Alexios III until the Russian occupation of Trebizond in 1916. Then, it appears that Russian authorities and some Greeks came to the conclusion that the entombed might be Alexios III, buried by Kalogiannes, inside the türbe. ${ }^{73}$ As the tomb of Alexios III was one of the principal memories of the Chrysokephalos complex mentioned by locals, it was only natural for them to think the tomb could belong to this emperor, rather than any of the other possible Byzantine emperors buried there. Uspensky and the archaeologist Feodor Morozov certainly excavated under the assumption that it was Alexios III, as is evident from Uspensky's diary and paperwork drawn up after the excavations. ${ }^{74}$ It was only when he sat down to write up his final report that Uspensky realized that it was far more likely that John IV would have built this tomb for his father rather than his great-grandfather.

Since Uspensky, the identification of the first body with a Turk and the second body with Alexios IV has remained unchallenged among Greek and Western

71 J.P. FAllmERAYER, Original-Fragmente, Chroniken, Inschriften und anderes Material zur Geschichte des Kaisertums Trapezunt. Abh. der Hist. Klasse der Bayer. Akad. der Wiss. 4/2 (1843) 31-108: 5-39.

72 As is evident in the history written by the head of Greek school in Trebizond, S. IoANNIDES,

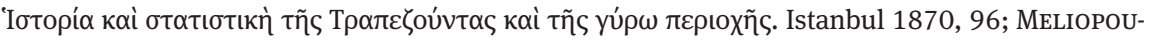

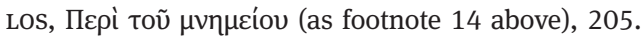

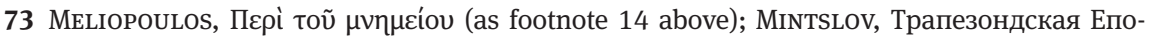
пея (as footnote 19 above), 45.

74 TsypкinA, Прибыл (as footnote 17 above), 142-144. The metropolitan of Trebizond, Chrysanthos, reproduces the document by which Uspensky handed over the bones of Alexios III: Philippides, 'Екк $\lambda \sigma^{\prime} \alpha$ (as footnote 14 above), 388. Feodor Morozov's inventory of artifacts kept in the Chrysokephalos Church records the bones of Alexios III: SHEgLov, Хранитель (аs footnote 25 above), 140-141. 
scholars. For their part, some Turks have accepted Uspensky's discoveries. ${ }^{75}$ Others have remained skeptical of Uspensky's discoveries, believing that the Russians destroyed their türbe and the Greeks took their compatriot's bones to Greece, claiming he was Alexios IV. ${ }^{76}$ But nonetheless, there have been attempts to reconcile Turkish tradition with Uspensky's discoveries. Some Turks have suggested that the Turks' identification of the entombed with Hoşoğlan 'Beautiful Youth' was simply a corruption of the name Kalogiannes in Greek, which means 'Beautiful John'. ${ }^{77}$ Little did these Turks know how recent both oral traditions were.

Such are the twists and turns of oral tradition, scholarly hypothesis, and national ambition that shaped the discovery and identification of the occupants of the Hoşoğlan türbe. After dissecting how and why these identifications were made by both Greeks and Turks, we can dismiss them both as improbable. From the meager existing evidence, it is clear that in 1819, there was a former ciborium tomb in use as a türbe. Turks claimed it belonged to a şahid or a dervish, while Greeks suspected the Turks were concealing the remains of saints. It was easy for Christians to imagine that the Turks were concealing them in a building with crosses on it. Over the course of the nineteenth century, folklore and scholarly hypothesis snowballed, as Turks attached local folklore to the site. Given the tomb's location, the Greeks and later Russians eventually came to the conclusion that the tomb of Alexios III mentioned by guides might be one and the same with the problematic türbe. After the liberation of Trebizond from Turkish rule, the Russian excavations symbolically sought to restore the site to the Greeks, or as Uspensky wrote in his diary "liberate the funerary monument from the Muslim hero and martyr."78 There was no incentive for Russian excavators to question the local tradition. The bones' discovery was a symbol of Russian science's triumph over (Turkish) ignorance, as Mintslov wrote in the Russian army's local newspaper, "such is the fate of archaeology, called upon to replace fantastical fabrications with truth.” Indeed, Uspensky's initial reports on the excavations appeared in the proceedings of the Russian Academy

75 LermioĞLu, Akçaabat (as footnote 26 above), 68-69; H. AlbayraK, Trabzon Orta Hisar ve çevresi. Ankara 1998, $166-172$.

76 Edhem, Trabzon'da Osmanli kitabeleri (as footnote 28 above), 64-65; AKARCA, Rus Politikaları (as footnote 33 above), 150 - 151; Efsaneler Diyarı Trabzon! Küzey Ekspres (2013); AKARCA, Imperial Formations (as footnote 33 above), 190-191.

77 I. SEvÜK, Yurttan yazılar. Ankara 1987, 233. Similarly, EDHEM, Trabzon'da Osmanlı Kitabeleri (as footnote 28 above), 64 note 1.

78 Tsypкina, Прибыл (as footnote 17 above), 142: “Прежде всего нужно было освободить погребальный памятник от мусульманского героя и мученика.” 
of Sciences. The bones also gave the Russian occupation a powerful symbol of the Pontic Greek past to legitimize their presence in the city to the Pontic Greeks, though the collapse of the Russian occupation in 1917 seems to have cut short these plans, as the proposed Chrysokephalos museum became a mosque once more.

\section{The identity of the entombed}

And so, we come to the question: who was buried in the tomb? Uspensky assumed that the first skeleton belonged to a Turk and the second to Alexios IV, but he was largely unaware of the tomb's history. Is it possible that his identifications were correct? Possibly, but the lack of certainty in early Muslim tradition about the identity of the entombed points to the fact that locals may have simply opened the tomb at some point between Evliya Çelebi and Minas Bzshkean's visits to the city and assumed they had found the bodies of Muslim holy men in a tomb with crosses scratched out. In the eastern Mediterranean, it was fairly common for people to open an ancient tomb and claim they had found the body of some holy man or hero, whose commemoration was symbolically significant for their community. For example, the Byzantines of Euchaneia near modern Amasya uncovered some poor fellow's body in the tenth century and attributed it to Saint Theodore Stratelates, though the whereabouts of the saint's corpse were previously unknown. ${ }^{79}$ As a comparandum to the Hoşoğlan tomb, we might take the tomb of Eyyüb el-Ensâri, a companion of the prophet Muhammad, who died during an attack on the city in the 670's in Istanbul's Ayvansaray neighborhood. According to Turkish tradition and late fifteenth century sources, shortly after the siege of Constantinople, the sheikh Akşemmedin at Mehmet II's bidding uncovered a sarcophagus with a skeleton inside near a fountain close to Blachernai Palace. He claimed he had found the body of the prophet's companion. ${ }^{80}$ But like Hoşoğlan's türbe, this tomb was no more than a Byzantine

79 N. OiкоnomidÈs, Le dédoublement de Saint Théodore et les villes d'Euchaïta et d'Euchaneia. $A B 104$ (1986), $327-335$.

80 M. ÇELIK, Akşemseddin Hazretleri ve yakın çevresi. Istanbul 2011, 42. For the legends and alternative views of the tomb, see F.W. HASLUCK, Christianity and Islam under the sultans. Oxford 1929, 515-516; P. WiтTEK, Ayvansaray, un sanctuaire privé de son héros. Annuaire de l'Institut de Philologie et d'Histoire Orientales et Slaves 11 (1951,) 505-526; S. Yerasimos, Légendes d'Empire: la fondation de Constantinople et de Sainte-Sophie dans les traditions turques. Paris 1990, 160 - 182; Ç. KAFESCIOĞLU, Constantinopolis/Istanbul: cultural encounter, imperial vision, and the construction of the Ottoman capital. University Park, PA 2009, 44-48. 
tomb reappropriated to assert Ottoman and Islamic dominance over the newly conquered city with a jihadi hero of the Islamic past. Though the original tomb has been replaced by the present türbe, the Italian traveler Giovan Maria Angiollelo (ca. 1470) found Eyyüb's tomb (San Giopo) located in an ancient little chapel/oratory (chiesola antica). ${ }^{81}$ Indeed, the Christian setting seems to have even embarrassed some Turks, as Turkish sources of the late fifteenth century explain that a Christian Byzantine emperor built a cupola (kubbe) for the prophet's companion. ${ }^{82}$ Like Trapezuntine Greeks, sixteenth-century Constantinopoli$\tan$ Greeks later forgot the tomb's occupant and hypothesized that the occupant must be the biblical Job through a deformation of Eyyüb. ${ }^{83}$

From the confusion of folk memory then, it seems likely then that the Muslims of Trebizond opened a Christian tomb and (un)wittingly attempted to situate it within the Islamic memory of the city. One need not assume that multiple bodies in a single sarcophagus is proof of an initial Christian and subsequent Islamic burial. While Muslims needed to demolish the tombs of Trebizond's metropolitans and emperors which lay within the Chrysokephalos monastery during its conversion into a mosque and medrese in order to open up the cluttered Christian space for Muslim use, a tomb just outside the main buildings probably was not subjected to much alteration given Trebizond's peaceful surrender. Gradually, the area around the former church became cluttered up with homes until eventually someone opened the forgotten tomb.

As to the identity of the Christian occupants of this tomb, Uspensky's original identification of the tomb as an imperial burial has some merit. As Nancy Sevcenko has illustrated, the ciborium tomb was used for monarchs throughout the later Byzantine period. ${ }^{84} \mathrm{~A}$ near exact representation of our ciborium tomb appears in the magnificent illuminated Alexander Romance painted in fourteenth-century Trebizond (fig. 3), depicting Alexander dressed as a Byzantine emperor laying to rest Darius. ${ }^{85}$ Gazing upon the image, it is easy to imagine the artist painting the burial of an emperor in his own time at the Chrysokephalos.

81 C. Bazzolo, Viaggio di Negroponte. Vicenza 1982, 26-27.

82 N. ÖztüRk, Oruç Beğ Tarihi (Osmanlı Tarihi 1288-1502). Istanbul 2014, 96; YeRASIMos, Légendes (as footnote 80 above), 39, 44.

83 WitTEK, Ayvansaray (as footnote 80 above), 508-509, 525.

84 ŠEvČEnKo, Tomb (as footnote 17 above).

85 The whole manuscript is viewable online at: http://eib.xanthi.ilsp.gr/gr/manuscripts.asp. 


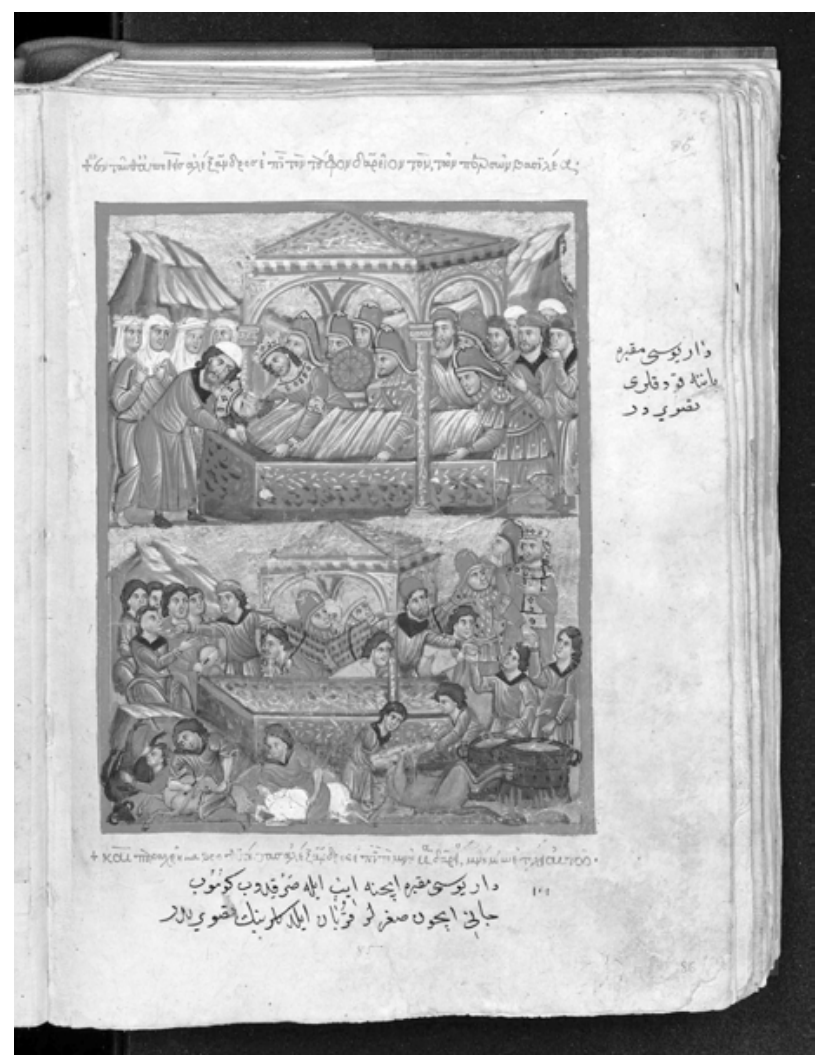

Fig. 3: Istituto Ellenico gr. 5, f. 86r, with the kind permission of the Istituto Ellenico

In the nineteenth century, a now destroyed ciborium tomb (fig. 4) was built in Trebizond for the former king of Imeretia, Solomon II (d. 1814). ${ }^{86}$ But the ciborium could also have been used for churchmen. In the late nineteenth century, Constantios (1830 - 1879) the metropolitan of Trebizond was buried in a now destroyed ciborium tomb at the Theoskepastos Monastery outside Trebizond's walls. ${ }^{87}$ From what we know of Trebizond, ecclesiastical burials in a ciborium tomb seem to have come later. Michael Panaretos speaks of tombs of metropolitans inside the Chrysokephalos church, while Byzantine burials of ecclesiastics

86 A. BRyer / D. Winfield / S. Ballance, The post-Byzantine monuments of the Pontos: a source book. Burlington, VT 2002, I 246-251.

87 Ibid., $102-108$. 


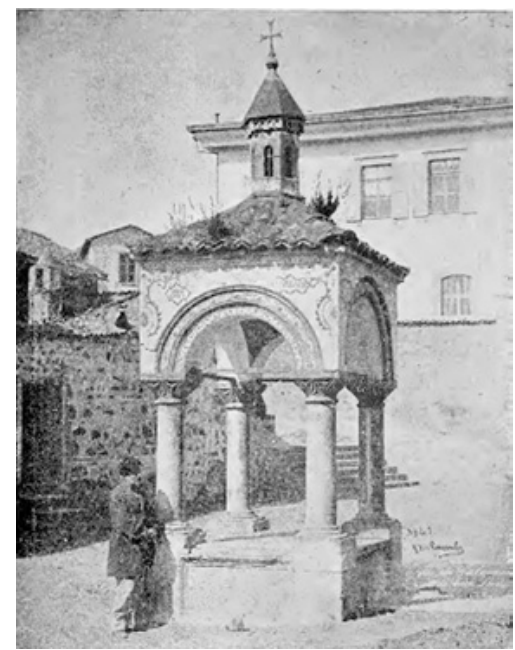

Fig. 4: Tomb of Solomon II, after Papami-

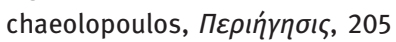

and abbots appear to have been either inside the church or outside with a funeral stele. ${ }^{88}$

Therefore, it seems likely that a monarch was buried in the tomb. The burial of members of the imperial family, if not multiple emperors, in the same sarcophagus was relatively common in Byzantium. From a list of emperors entombed at the mausolea next to the Holy Apostles church in Constantinople, it is clear that 2 , 3, even 4 people might have been buried in the same sarcophagus. ${ }^{89}$ And this was not just an issue of limited space in these mausolea. For example, John II Komnenos, the Grand Komnenoi's ancestor, included a provision in his regulations for the newly erected Pantokrator Monastery that would allow his son and heir to be buried in his father's sarcophagus if he so desired..$^{90}$ We know this also happened at Trebizond from Constantine Loukites' funeral oration for the emperor Alexios II (1297-1330). After listing all the emperors of Trebizond, Loukites addresses Alexios I (1204-1222), the founder of the dynasty at Trebizond:

88 KARPov/ShUKURov/Kryukov, Панарет (as footnote 70 above), 100; BRYER/WinfIELD, By-

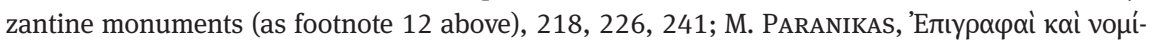

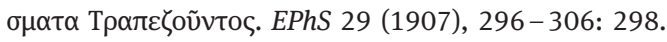

89 Constantin VII Porphyrogénète, Le livre des cérémonies, ed. G. DAGron et al. CFHB, 52. Paris 2020, $275-287$ = J. REISKE, De ceremoniis aulae Byzantinae libri duo. Bonn 1829, 642 - 649. 90 P. Gautier, Le typikon du Christ Sauveur Pantocrator. REB 32 (1974), 1-145: 79. 


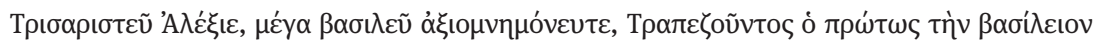

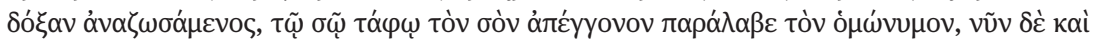

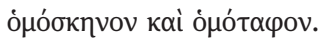

Thrice noble Alexios, great king worthy of memory, who first assumed the imperial dignity, take in your tomb your great-grandson with the same name, who is now under the same roof and in the same tomb. ${ }^{11}$

Thus the two Alexioi were entombed together under the same roof. For the sake of argument, it is tempting to identify the occupants of the ciborium tomb as Alexios I and II. We know from Panaretos that Alexios I's successor, Andronikos Gidos (1222-1235) built a koimeterion in the Chrysokephalos complex before he died, where other members of the Grand Komnenoi were buried. ${ }^{92}$ If Alexios I's tomb had stood in the same structure, one would imagine that Loukites would have mentioned all of the Grand Komnenoi under the same roof, but instead he singles out only Alexios I. This implies that Alexios I was buried in a separate

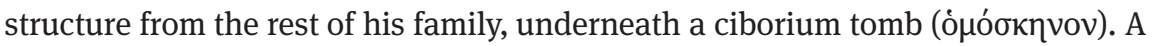
special tomb structure such as this would have been a fitting way for the dynasty to celebrate the founder of the empire of Trebizond.

Identifying the entombed as Alexios I and Alexios II, or even just two unknown imperials, is only hypothetical. We know nothing specific about how they died, and so the unusual skull of the first skeleton is of little help. Further scientific work needs to be done on the bones preserved by the Greeks to clarify the identity of the entombed. There is an added urgency to such an examination, as it is not just Uspensky's second skeleton who is presently being revered as Alexios IV in Greece. Archaeological standards were lax in 1916, and the excavators carelessly mixed up the skeletons they discovered..$^{93}$ When Uspensky departed Trebizond in 1917, he tells us that he deposited with the Greek metropolitan Chrysanthos Philippides "the bones of Alexios IV discovered in the marble sarcophagus along with the other bones [recovered] from the Church of Saint Eugenios." 94 In theory, Uspensky delivered two separate boxes with separate skeletons to Chrysanthos. However, this is flatly contradicted by Chrysanthos

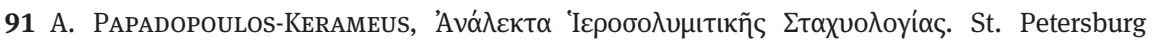
1891, I 425.

$92 \mathrm{KARPov} / \mathrm{ShuKUROV} / \mathrm{Kryukov}$, Панарет (as footnote 70 above), 112.

93 On the Saint Eugenios excavation, see TsyркіNA, Еспедиция (as footnote 33 above), 225 226.

94 UsPensky, Усыпальница (as footnote 15 above), 14: “были переданы имъющимъ довъріе отъ митрополита лицамъ, подъ ихъ расписку, найденныя въ мраморномъ саркофагъ кости Алексъя IV, вмъстъ съ другими костями изъ церкви св. Евгенія.” F. USPENSKY, Очерки из истории Трапезунтской империи. St. Petersburg 1929, 43. 
himself who writes, "Uspensky notes that these remains [the Saint Eugenios bones] were handed over to the sacred metropolitanate of Trebizond. This is not accurate. Uspensky concealed his discovery of these remains [Saint Eugenios] from the sacred metropolitanate, and he only handed over to it the bones of the emperor Alexios IV." 95

Chrysanthos had little love for Uspensky, whom he labeled in his memoirs a 'Greek-hater' and a 'panslavist', who was unwilling to share his findings with the metropolitan. ${ }^{96}$ But in this case, Chrysanthos was actually deceived by Uspensky. It appears that Uspensky delivered a single chest in which were mixed up the remains of 'Alexios IV', 'Hoşoğlan', and bones from the church of Saint Eugenios. When the Russian archaeological team excavated these bodies, they showed an alarming lack of concern for ensuring that the bodies were properly separated. All the bodies were placed in a single chest kept under lock and key in the Chrysokephalos Church. Dr. Iakov Kefeli, a Russian Turkish-speaker who had been appointed to the Trabzon city council, reports in his unpublished memoirs:

\begin{abstract}
потомъ никакъ не могли разобраться въ грудь человъческихъ костей, чтобы возстиноаить вновь скелеты. Черезъ ньсколько стольтій тльнія святой, императоръ и раб - всь на одно лицо. Ньтъ разницы между римляниномъ, грекомъ и туркомъ. Всь равны въ своемъ ничтожествђ! Всь вмБсть мирно опятъ. Жизнь-борьба. Миръ-могила! Мнь показывали и этотъ шкафъ, и этотъ ящикъ, и его содержимое.

Later, they were completely unable to separate the human bones in the chest in order to restore the skeletons again. After centuries of decay, the saint, the emperor, and the slave [Hoşoğlan], they all became a single person. There was no difference between Roman, Greek, and Turk. All were equal in their insignificance! All together in peace again. Life-a struggle. Peace-a tomb! This closet, the chest, and its contents were shown to me. ${ }^{97}$
\end{abstract}

As shocking as Kefeli's testimony is, it is independently corroborated by Uspensky's occasional collaborator Sergei Mintslov, whose diary recounts a meeting with Uspensky on September, 24, 1916, about a week after he and his collaborator Feodor Morozov completed their excavations. Allegedly, Uspensky showed him the chest and pointed at the strange skull of 'Hoşoğlan', insisting that it was the skull from Saint Eugenios. Unbeknownst to Uspensky, Mintslov had clandestinely stashed the Eugenios skull for his personal collection. Nonplussed,

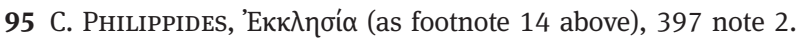

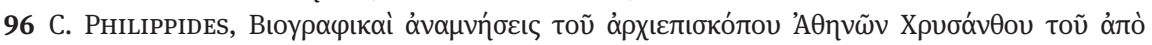

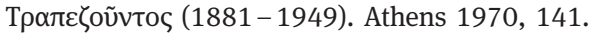

97 Bakhmeteff Archive of Russian and East European Culture, Kefeli Papers, Box 1, File "B Tpaпезунде с генералом Шварцом,” f. 34. 
Mintslov comments, "I did not object. The old man is mixing up and forgetting everything!"98 Based on these three independent testimonies, Uspensky and the Russian excavators clearly surrendered a mixed-up skeleton to Chrysanthos without communicating this fact to the Pontic Greeks or the scholarly community at large. When Uspensky wrote that he had surrendered the bones of Alexios IV and Saint Eugenios to Chrysanthos, he was truthful, but only half-truthful, as he wished to conceal his and his team's oversight.

In light of all this, scientific study of the skeletons could finally disentangle the mystery of the skeletons found in the ciborium tomb and, if the Grand Komnenoi are buried here, contribute to our knowledge of what may be the only remains of a Roman emperor. For a century or more, the Turks revered the remains of Byzantine(s) as theirs. Then Uspensky excavated the türbe and 'liberated' for Pontic Greeks the bones of their former emperor at a moment when their community needed a symbol of their past most. Now after a century of Greek reverence for 'Alexios IV', one may hope it is time to reopen the case and finally examine the bones to resolve the mystery of this tomb.

98 MintSLov, Трапезондская Епопея (as footnote 19 above), 130: “Я не сталъ возражать. Старецъ все путаетъ и забываетъ!” 
